УДК 37.035.6

\title{
ТРАДИЦИИ МАЛОЙ РОДИНЫ В ФОРМИРОВАНИИ ПАТРИОТИЗМА У МЛАДШИХ ШКОЛЬНИКОВ
}

\author{
Заббарова Марина Геннадьевна \\ к.п.н., доцент \\ Муниципальное бюджетное общеобразовательное \\ учреждение города Ульяновска «Средняя школа №64» \\ Журавлёва Светлана Рамилевна \\ Муниципальное бюджетное общеобразовательное учреждение \\ города Ульяновска «Губернаторский инженерный лицей №102»
}

\begin{abstract}
Аннотация: статья посвящена выявлению значимости формирования патриотизма у подрастающего поколения, которое в современных условиях должно опираться на традиции родного народа, опыт предшествующих поколений, вековую историю России и конкретного региона. Поэтому возникает необходимость изучения своеобразия культуры и традиций каждого субъекта государства, как части великой России. В статье выделены научные предпосылки, которые необходимо учитывать в процессе формирования патриотизма у младших школьников посредством традиций региона. Представлены наиболее эффективные технологии, формы организации учебновоспитательного процесса. Показаны направления, по которым учитываются изменения, происходящие у младших школьников, диагностические методики для учета данных изменений. Обозначена практическая значимость результатов исследования.

Ключевые слова: патриотическое воспитание, патриотизм, формирование патриотизма, традиции малой родины, младший школьный возраст, методологические принципы формирования патриотизма у школьников, педагогические технологии.
\end{abstract}




\title{
THE LOCAL MOTHERLAND TRADITIONS INFLUENCE THE FORMATION PRIMARY SCHOOL CHILDREN'S PATRIOTISM
}

\section{Zabbarova Marina Gennadevna Zhuravleva Svetlana Ramilevna}

\begin{abstract}
: the article is devoted to the identification and the importance of the formation of patriotism in the younger generation, which in modern conditions should be based on the traditions of the native people, the experience of previous generations, the age-old history of Russia and a particular region. Therefore, there is a need to study the uniqueness of the culture and traditions of each subject of the state, as part of the great Russia. The article highlights the scientific prerequisites that must be taken into account in the process of forming patriotism among younger schoolchildren through the traditions of the region. The most effective technologies and forms of organization of the educational process are presented. The directions in which changes occurring in primary school children are taken into account are shown, as well as diagnostic methods for taking these changes into account. The practical significance of the research results is indicated.
\end{abstract}

Key words: patriotic education, patriotism, formation of patriotism, traditions of the local motherland, primary school age, methodological principles of formation of patriotism among schoolchildren, pedagogical technologies.

«Как у маленького деревиа, еле поднявшегося над землей, заботливый садовник укрепляет корень, от мощности которого зависит жизнь растения на протяжении нескольких десятилетий, так взросльй должен заботиться о воспитании у своих детей чувства безграничной любви к малой родине».

В.А. Сухомлинский

В России с начала XXI века отмечаются процессы активизации воспитательной составляющей в деятельности образовательных организаций. Происходит возрождение значения и востребованности гражданских, патриотических взглядов и убеждений. Патриотизм выступает основой государственности, основой нашего будущего. Складывается понимание того, 
что чувство любви к Отечеству должно формироваться не стихийно, а быть воспитано в человеке семьёй, школой, системой образования.

Патриотическое воспитание в настоящее время должно основываться на высших духовных ценностях российского народа, опираться на духовные традиции родного народа, опыт предшествующих поколений, вековую историю России и конкретного региона. Именно поэтому возникает необходимость изучения своеобразия этнокультур каждого субъекта государства, как части великой России, уникальность которой складывается из особенностей конкретной республики, области, муниципального образования.

Перед многонациональной Ульяновской областью, где разные народы живут в дружеском общении и постоянном взаимодействии друг с другом, в современных условиях стоит задача выработки такого содержания патриотического воспитания школьников, которое в наибольшей степени будет способствовать формированию патриотов [1, с. 378].

Для современного человека стало актуально восстанавливать культурноисторические связи со своей малой родиной, с родным краем. Знакомство с историческим прошлым, его культурой, традициями значимо в патриотическом воспитании личности. В «Концепции духовно-нравственного развития и воспитания личности гражданина России» определены базовые национальные ценности производные от национальной жизни России во всей её исторической и культурной полноте, этническом многообразии, хранимые в социальноисторических, культурных, семейных традициях многонационального народа России. Одной из составляющих системы нравственных ценностей является патриотизм - любовь к России, к своему народу, к своей малой родине [2, c. 18].

Формирование патриотизма выступает как одно из условий дальнейшего общественного прогресса. Как отмечают А.Н. Вырщиков, С.Н. Климов, М.Б. Кусмарцев, И.В. Метлик исторический опыт становления и развития нашего Отечества указывает на то, что важнейшим средством формирования гражданского общества, укрепления единства и целостности многонациональной Российской Федерации является патриотизм [3].

В современном понимании патриотизм - это многовариантное понятие, которое имеет много различных определений. И.Ф. Харламов указывает на то, что патриотизм как единство моральных и эстетических чувств и черт поведения, включает в себя любовь к Родине, активный труд на её благо, соблюдение и сохранение традиций своего народа, преданность и любовь к родному краю, готовность и умение защищать его, стремление к укреплению 
чести и достоинства Родины, мужество и самоотверженность, нетерпимость к расовой и национальной неприязни, компетентностное отношение к традициям и обычаям других стран и народов и стремление к сотрудничеству с ними [4, c. 389].

Патриотизм является центральным звеном всех сторон жизни общества (экономической, политической, социокультурной, духовной и т.д.). В системе общественных отношений интегративностью патриотизма выступают следующие характеристики:

- гармоническая, которая основана на любви к своей Родине, ведёт к гармонизации системы «личность - коллектив - общество - государство» в пространстве ценностей, смыслов, идеалов и т.д.;

- императивная - указывающая на необходимость следования социокультурным регулятивам (традиции, обычаи, идеалы и т.д.) и духовным стимуляторам (историческая память, преданность своей Родине, ответственность за будущее и др.) [5, с.7].

Теоретический анализ психолого-педагогической, методической литературы позволил уточнить понятие «патриотизм»- это любовь к своей малой Родине, своему краю, преданность своему Отечеству, своим традициям, всему, что связано с родным краем.

Как видно, из приведённого выше, традиции малой родины являются значимым средством в формировании патриотизма у обучающихся. Данной проблеме уделяли внимание в своих исследованиях такие ученые как Н.А. Бердяев, Б.П. Вышеславцев, Г. Гегель, И.А. Ильин, Н.И. Кареев, П. Корсавин, К.Н. Леонтьев, В. Плеханов, В.В. Розанов, В.С. Соловьев и др.

Традиции, являясь одним из важнейших компонентов культуры, направлены на сохранение и воспроизводство материально-духовных ценностей и общественных отношений. На основе чувств привязанности к родным людям, родному краю, природе, традициям формируется и укрепляется любовь к Родине. По мнению Н.И. Никитина, развитие у детей чувства любви к родному краю становится одним из важнейших направлений работы начальной школы в процессе формирования у них патриотизма [6, с. 184].

Отношение человека к народным традициям тесно связано с отношением к Родине, родным местам, языку; уважение к её прошлому, к традициям и обычаям своего народа, знание его истории и культуры, принятие их в качестве ценности; активным и сознательным участием в трудовой деятельности, сочетая личные и общественные интересы [7, с. 214].

Исследование процесса формирования патриотизма у школьников 
посредством народных традиций опирается на комплекс методологических принципов:

- сущцностного анализа - связан с соотнесением в изучаемых явлениях общего, особенного и единичного, раскрытием законов их существования и функционирования, условий и факторов их развития, возможностей целенаправленного их изменения; предполагает движение исследовательской мысли от описания к объяснению, а от него - к прогнозированию развития педагогических явлений и процессов;

- объективности - заключается во всестороннем учете порождающих то или иное явление факторов, условий, в которых они развиваются, адекватности исследовательских подходов и средств, позволяющих получить истинные знания об объекте;

- единства логического и исторического - требует в каждом исследовании сочетать изучение истории объекта (генетический аспект) и теории (структуры, функций, связей объекта в его современном состоянии), а также перспектив его развития;

- единства воспитательного воздействия со стороны педагогов, семьи и социокультурного сообщества обеспечивает приобщение их к процессу познания и освоения народных традиций, ориентирует на формирование личностной культуры, национального самосознания;

- краеведческий - предполагает использование народных традиций, бытующих на территории Симбирско-Ульяновского Поволжья.

Перед современной системой образования стоят важные задачи по приобщению школьников к традициям народов, проживающих в конкретном регионе с целью формирования у них патриотизма: изучить традиции своего края; уважительно относится к своим корням, чтить и уважать память предков; приобщить детей к истокам традиционной народной культуры родного края.

Следует выделить несколько условий организации педагогического процесса, направленного на формирование патриотизма у школьников посредством традиций малой родины:

- выявлена сущность, возможности традиций малой родины как средства формирования патриотизма младших школьников;

- разработано и используется дидактическое обеспечение процесса ознакомления младших школьников с традициями народов Поволжья;

- использование современных технологий, эффективных форм и средств организации учебно-воспитательного процесса; 
- знакомство обучающихся с различными формами народной традиционной культуры: народные праздники, прикладное искусство, народное творчество, фольклор, элементы труда и быта, традиционные костюмы и др.;

- разработаны уроки, внеурочные занятия, направленные на формирование патриотизма у младших школьников посредством освоения народных традиций.

Считаем, что с целью изучения традиций малой родины в начальных классах возможно использование на уроках и во внеурочной деятельности следующих средств: устного и музыкального народного творчества (игры, песни, сказки, загадки и т.п.), декоративно-прикладного творчества (народные костюмы, вышивка, ткачество, резьба и др.), предметы быта (домашняя утварь). Этот мир очень яркий, впечатляющий и поэтому интересен для младших школьников. Тем более что они могут стать активными участниками этой деятельности.

Одним из значимых средств формирования патриотизма у младшего школьника является устное народное творчество, которое с интересом усваивается детьми младшего возраста в силу его эмоциональности, образности. К жанрам устного народного творчества относятся сказки, былины, пословицы и поговорки, загадки. Знакомство с произведениями устного народного творчества позволяет сформировать уважение к родителям, традициям малой родины, любовь к природе родного края, своему народу, его истории, подвигам и победам.

Большое воспитательное значение ученые отводят народным сказкам, так как в них отражается жизнь народа, его лучшие черты, обычаи, быт, окружающая природа, а также представление о мировоззрении и психологии народа. Таким образом, считаем, что сказки являются эффективным средством в нашем исследовании.

Поэтому нами разработаны и реализованы на практике внеурочные занятия с использованием творческих заданий, компьютерных игр (кроссворды, сканворды, игры «Крестики-нолики», «Своя игра», «Поле чудес») по сказкам народов Поволжья: «Колебятко», «Два купца», «Заяц-слуга», «Соловей», «Лиса-плясунья», «Иван-батыр», «Куйгорож», «Ленивица», «Как появилась первая гусыня» и др.

Электронная энциклопедия «Поволжье - наш край родной» и рабочая тетрадь на печатной основе - являются дидактическим материалом, используемым как на уроках, так и во внеурочной деятельности. Содержание энциклопедии включает в себя основные информационные разделы, 
отражающие сведения о населении, хозяйстве, традициях, быте, одежде, искусстве народов населяющих наш край.

Рабочая тетрадь используется для организации самостоятельной работы учащихся на внеурочных занятиях. В ней представлены различные творческие здания, соотнесённые с разделами электронной энциклопедии. Например, разделу «Традиционные костюмы», соответствуют следующие задания из рабочей тетради: «Укажи основные элементы народного костюма», «Раскрась мордовский национальный костюм», а так же вкладыш тетради с заданием: «Вырежи и собери девочку в русском народном костюме» и др.

Образовательный процесс в современной школе немыслим без эффективных технологий, призванных содействовать развитию творческих, познавательных способностей обучающихся, формированию навыков саморазвития и самообразования. Этим требованиям отвечает проектная деятельность.

Рассмотрим организацию проектной деятельности с младшими школьниками в процессе формирования у них патриотизма на примере проекта «Взгляд в прошлое».

На первом занятии учитель представляет традиции малой родины в виде обзорной экскурсии по Ульяновской области. На последующих занятиях внеурочной деятельности учащиеся создают информационные проекты на начальных этапах проектной деятельности (форма представления - альбом) и творческие или исследовательские проекты в третьем и четвертом классах (форма представления - презентация или видеоролик, альбом и пояснительная записка к ним). Темы учащиеся выбирают самостоятельно из предложенного перечня: «Гордимся земляками»,«Знаменитые люди», «Достопримечательности города (области)», «Памятники природы родного края», «Мы разные, но мы вместе», «Народные праздники», «Традиции моей семьи», «По одёжке встречают», «Где блины - там и мы» и другие.

В процессе работы над проектами учащиеся учатся находить информацию в различных источниках (книги, энциклопедии, беседы со старшим поколением и т.п.), выделять главное, систематизировать, оформлять, презентовать. Развивают творческие способности и исследовательские навыки. Самое главное узнают больше о своей малой родине, её людях, природе, традициях!

Изменения, происходящие с учащимися начальных классов, в процессе формирования патриотизма посредством традиций малой родины проводятся по следующим направлениям: 
- наличие представлений о патриотизме, знаний о традициях, культуре, народов, проживающих в регионе;

- система ценностных ориентаций и отношений к малой родине (отношение к Родине, своему народу, традициям);

- готовность к сохранению культуры и традиций народов Поволжья, участие в патриотической созидательной деятельности.

Для диагностики сформированности патриотизма у младших школьников за основу взяты диагностические методики Т.М. Масловой, Л.М. Лапшиной, Е.В. Соловьёвой и Л.И. Царенко, по которым можно выявить проявление патриотических чувств младших школьников по отношению к малой родине, определить уровень патриотической воспитанности, а также общие знания о патриотизме, культуре и традициях малой родины. Данные методики адаптированы с учетом возрастных особенностей детей младшего школьного возраста и сведений о регионе, региональных традициях.

Отметим практическую значимость результатов исследования:

- разработанная программа, выявленный комплекс педагогических условий, направленный на эффективность формирования патриотизма у младших школьников посредством традиций малой родины, могут быть приняты за основу в патриотическом воспитанности подрастающего поколения;

- экспериментально апробированный диагностический инструментарий для определения уровня сформированности патриотизма младших школьников (комплекс диагностических методик, в том числе авторские диагностические методики);

- разработанные уроки и внеурочные занятия, дидактический материал, результаты проектной деятельности школьников;

- методические рекомендации, созданные в ходе исследования, могут использоваться заместителями директоров по воспитательной работе, воспитателями, учителями и педагогами-психологами в практике образовательных организаций, а также студентами психолого-педагогических специальностей учреждений среднего и высшего профессионального образования.

Считаем, что формирование патриотизма играет одну из главных и важных частей в развитии личности ребенка на современном этапе. Так как патриотизм является одним из элементов структуры отношение к малой родине, к ее традициям и культуре народа, то важно, чтобы ребенок уже с 
малых лет был разносторонне развит и приобщен к истории и традициям народов своего региона. Знакомство с историей малой родины, её культурой и традициями - это, несомненно, один из самых важнейших шагов на пути к становлению маленького гражданина и настоящего патриота.

\section{Список литературы}

1. Тихонова А.Ю., Гринёва Е.А., З Заббарова М.Г. Патриотическое воспитание подрастающего поколения: этнокультурный аспект // Современные наукоемкие технологии. - 2016. - № 8-2. - C. 378-382; URL: http://toptechnologies.ru/ru/article/view?id=36165.

2. Данилюк А.Я. Концепция духовно-нравственного развития и воспитания личности гражданина России / А.Я. Данилюк, А.М. Кондаков, В.А. Тишков. - М.: Просвещение, 2010. -24 с.

3. Вырщиков А.Н., Климов С.Н., Кусмарцев М.Б., Метлик И.В. Российский патриотизм: истоки, содержание, воспитание в современных условиях. Учеб. пособие // под общ. Ред. А.К. Быкова и В.И. Лутовинова. - М.: Изд. «Планета», 2010. - 336 с. - (Воспитательная работа).

4. Харламов И.Ф. Педагогика: Учеб. пособие. - 2-е изд. - М.: Высшая школа, 2011. - 576 с.

5. Настольная книга по патриотическому воспитанию школьников. Методическое пособие для школьных администраторов, учителей, классных руководителей, педагогов дополнительного образования / авт.-сост. А.Н. Вырщиков, М.Б. Кусмарцев, А.П. Пашкович. - М.: Глобус, 2007. - 330 с. (Воспитательная работа).

6. Никитин Н.И. К истокам патриотизма // Отечественная история. - 2004. - №3. - С. 183-187.

7. Борытко Н.М. Педагогика: учеб. пособие для студ. высш. учеб. заведений / Н.М. Борытко, И.А. Соловцова, А.М. Байбаков; под ред. Н.М. Борытко. - М.: Издательский центр «Академия», 2007. - 496 с.

(C) М.Г. Заббарова, С.Р. Журавлёва, 2021 